\title{
Anticancer effects of Bilberry anthocyanins compared with NutraNanoSphere encapsulated Bilberry anthocyanins
}

\author{
SETH P. THIBADO ${ }^{1}$, JERRY T. THORNTHWAITE ${ }^{2}$, THOMAS K. BALLARD ${ }^{2}$ and BRANDON T. GOODMAN ${ }^{2}$ \\ ${ }^{1}$ Department, of Chemistry, Union University, Jackson, TN 38305; \\ ${ }^{2}$ Cancer Research Institute of West Tennessee, Henderson, TN 38340, USA
}

Received April 26, 2017; Accepted October 27, 2017

DOI: $10.3892 / \mathrm{mco} .2017 .1520$

\begin{abstract}
Rapidly accumulating laboratory and clinical research evidence indicates that anthocyanins exhibit anticancer activity and the evaluation of bilberry anthocyanins as chemo-preventive agents is progressing. It has previously been demonstrated that anthocyanins upregulate tumor suppressor genes, induce apoptosis in cancer cells, repair and protect genomic DNA integrity, which is important in reducing age-associated oxidative stress, and improve neuronal and cognitive brain function. Bilberry anthocyanins have pronounced health effects, even though they have a low bioavailability. To increase the bioavailability, Bilberry was encapsulated in $5.5 \mathrm{~nm}$ diameter liposomal micelles, called NutraNanoSpheres (NNS), at a concentration of $2.5 \mathrm{mg} / 50 \mu \mathrm{l}$ [25\% (w/w) anthocyanins]. These Bilberry NNS were used to study the apoptotic/cytotoxic effects on K562 Human Erythroleukemic cancer cells. Flow cytometric fluorescent quantification of the uptake of propidium iodide in a special cell viability formulation into dead K562 cells was used to determine the effects of Bilberry on the viability of K562 cells. The concentrations of Bilberry that demonstrated the greatest levels of percentage inhibition, relative to the control populations, were biphasic, revealing a $60-70 \%$ inhibition between $0.018-1.14 \mathrm{mg} / \mathrm{ml}(\mathrm{n}=6)$ and $60 \%$ inhibition at $4 \mathrm{mg} / \mathrm{ml}$. The lowest percentage inhibition (30\%) occurred at $2 \mathrm{mg} / \mathrm{ml}$. The lethal dose 50 was determined to be $0.01-0.04 \mathrm{mg} / \mathrm{ml}$ of Bilberry per $105 \mathrm{~K} 562$ cells at $72 \mathrm{~h}$ of cell culture exposure. At $48 \mathrm{~h}$ incubation, the highest percentage of inhibition was only $27 \%$, suggesting involvement of a long-term apoptotic event. These levels, which demonstrated direct cytotoxic effects, were 8-40 times lower than levels required for Bilberry that is not encapsulated. The increase in bioavailability with the
\end{abstract}

Correspondence to: Dr Jerry T. Thornthwaite, Cancer Research Institute of West Tennessee, 114 East Main Street, Henderson, TN 38340, USA

E-mail: jtt@criwt.com

Key words: Bilberry, anthocyanins, cancer, micelle, natural
Bilberry NNS and its water solubility demonstrated the feasibility of using Bilberry NNS in cancer patient clinical trials.

\section{Introduction}

Anthocyanins are the chemical components that result in the intense color to many fruits and vegetables, such as bilberries, blueberries, red cabbages and purple sweet potatoes. Rapidly accumulating in vitro and in vivo evidence indicates that anthocyanins have cancer preventive and anti-cancer activity. Bilberry anthocyanins were shown to be effective cancer preventive agents in 25 colorectal cancer patients (1). Anthocyanins treated cancer cells reveal upregulation of tumor suppressor genes and intracellular-signaling cascades as common molecular targets for anthocyanins (2). Defect in apoptosis has been implicated as a major cause of resistance to chemotherapy. Anthocyanins induced apoptosis in cancer cells via activation of redox-sensitive caspase 3-pathways were observed in B-cell chronic lymphocytic leukemia (B-CLL), but had no effect in normal peripheral blood cells (3). Furthermore, Bilberry extracts exhibited strong pro-apoptotic activity through redox-sensitive caspase 3 activation-related mechanism in B-CLL cells involving dysregulation of the Bad/Bcl-2 pathway (3). Interestingly, bilberry anthocyanins also synergistically suppress growth and invasive potential of human non-small-cell lung cancer cells (4). The development of a better delivery system for Bilberry anthocyanins would significantly enhance their cancer prevention and treatment effectiveness. Herein is reported such a system utilizing the NutraNanoSphere ${ }^{\mathrm{TM}}$ (NNS) micellation of Bilberry.

\section{Materials and methods}

Cell line and media production. Experiments were performed using a chronic myelogenous leukemia K-652 cell line purchased from the American Type Culture Collection.

The tissue culture media was made by adding $5 \mathrm{ml}$ of $100 \mathrm{X}$ penicillin-streptomycin $(10,000$ units penicillin with $10 \mathrm{mg}$ of streptomycin/ml), $5 \mathrm{ml}$ of $200 \mathrm{mM}$ sterile-filtered L-Glutamine (both from Sigma-Aldrich, St. Louis, MO, USA), $5 \mathrm{ml}$ of Cellgro sodium 100X bicarbonate solution (Cellgro Mediatech, Herndon, VA, USA), and $50 \mathrm{ml}$ of fetal calf serum (Atlanta Biologicals, Flowery Branch, GA, USA) to $500 \mathrm{ml}$ of Minimum Essential Media, Alpha 1X, with Earle's 
salts without ribonucleotides, deoxyribonucleotides, and no L-glutamine (Cellgro Mediatech).

Viability stain. The viability stain used for analysis with the flow cytometer was developed by Dr Jerry Thornthwaite. The evidence that showed the viability stain, which uses a special medium and dye exclusion with propidium iodide (PI) (Sigma-Aldrich), was effective in measuring cell viability was shown in two ways. Firstly, $500 \mu 1$ portions of K562 cells $\left(5 \times 10^{6} / \mathrm{ml}\right)$ were heated as triplicates in a $56^{\circ} \mathrm{C}$ water bath for $\leq 20 \mathrm{~min}$. At $5 \mathrm{~min}$ intervals, $500 \mu \mathrm{l}$ of the viability reagent was added to the timed samples at room temperature. All samples were run after a $2 \mathrm{~min}$ incubation at room temperature on the Accuri Flow Cytometer (BD Biosciences, San Jose, CA, USA). Also, K562 cell viability was measured directly from cell cultures in which $100 \mu \mathrm{l}$ samples from the cell culture were added to $100 \mu \mathrm{l}$ of the viability stain. After incubation for five min at room temperature, the samples were suspended and analyzed using flow cytometry. Forward light scatter was used to gate on the K562 cells and analyze the number of viable cells within the established control viability gate in the $585 \pm 20 \mathrm{~nm}$ fluorescence red channel. Typical control cultures with $95-99 \%$ viability were used to establish the boundary of the viable cells, which only showed passive background staining on the cell surface.

Encapsulated reagent. Bilberry NNS were obtained from Dr Lothar Haegeler of X-Labs (Switzerland-Singapore) and had a concentration of had a concentration of $2.5 \mathrm{mg} / 50 \mu \mathrm{l}$ or $50 \mathrm{mg} / \mathrm{ml}$. The anthocyanin concentration in the micellized Bilberry was $25 \%(\mathrm{w} / \mathrm{w})$.

Average diameter measurements of the NNS. The samples were diluted by volume in a ratio of 1:6 with DI Water and filtered by a $0.45 \mu \mathrm{m}$ Nylon membrane to remove any dust contaminants. The Zetasizer ZSP (Malvern Instruments, Malvern, UK) was used with a backscattering angle of 173 degrees to measure the particle size by dynamic light scattering. A non-negative least squares algorithm was used to generate the size distribution by intensity, which indicated the diameter of the major population for the NNS. The intensity data was then converted to a mass or volume distribution to compare relative amounts of each size population, which indicated the percentage of the sample represented in the respective population.

Sample preparation and cell counting. In all assays, viable cell counts were obtained by mixing $100 \mu \mathrm{l}$ of a cell culture with $100 \mu \mathrm{l}$ of viability stain. All samples were analyzed within an hour after room temperature incubation for at least $5 \mathrm{~min}$. The percentage viability was stable for $\leq 2 \mathrm{~h}$. A $10 \mu \mathrm{l}$ portion of each sample was run through the Flow Cytometer at a medium flow setting. The resulting number was multiplied by 200 to determine the number of viable cells $/ \mathrm{ml}$.

Cell growth plate preparation. The cells that were counted were then diluted with the media to a concentration of $1 \times 10^{5}$ cells $/ \mathrm{ml}$. A $500 \mu \mathrm{l}$ portion of the cells was added to each well of the 48 -well plate. The plates incubated in a Forma Scientific $\mathrm{CO}_{2}$ water-jacketed incubator at a temperature

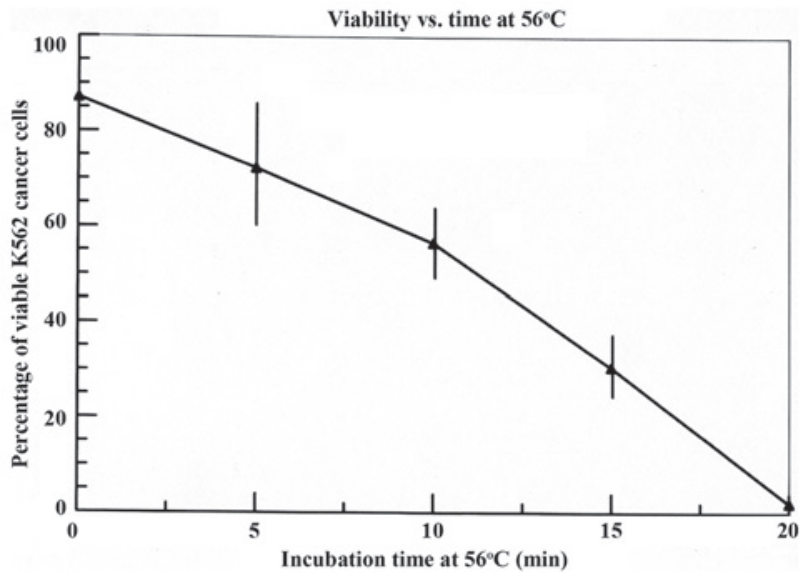

Figure 1. Percentage of viable K562 cells as a function of time exposure in a $56^{\circ} \mathrm{C}$ water bath. Standard deviation bars $(n=3)$ are shown.

of $37.2^{\circ} \mathrm{C}$ for $48 \mathrm{~h}$ to allow the cells to enter the exponential growth phase.

Addition of compounds. After incubation for $48 \mathrm{~h}$, the stock sample compounds were diluted accordingly, by a factor of two for up to eight dilutions. A $50 \mu 1$ sample was added to each well, and $\leq 6$ replicates of each dilution to the wells were done. A total of $50 \mu \mathrm{l}$ of cell culture media was added to each control well. Once finished, every well contained $550 \mu$ l. The plates were incubated for $48 \mathrm{~h}$.

Cell processing, staining, and analysis. Up to six replicates at each concentration, starting with the controls that were used to set the gates for viability, were suspended with a $500 \mu \mathrm{l}$ pipet, and $100 \mu \mathrm{l}$ portions were added to $2 \mathrm{ml}$ 96-well analysis tubes. After all of the samples were added to the tubes, $100 \mu \mathrm{l}$ of the viability stain were added using an 8-channel multipipettor, and the tray was shaken slightly and incubated for $\geq 5 \mathrm{~min}$. All samples were analyzed within an hour after room temperature incubation for at least $5 \mathrm{~min}$. The viability-stained cells were stable for at least $2 \mathrm{~h}$ at room temperature. A $10 \mu \mathrm{l}$ portion of each sample was run through the Flow Cytometer at a medium flow setting. The resulting number was multiplied by 200 to determine the number of viable cells $/ \mathrm{ml}$.

Percentage cell viability. Control cells were used to set the forward angle light scatter gate for the entire cell population gate for the viable cells less debris to the left of the scatter peak. The resulting fluorescent peak population of cells comprised the viable cells (95-97\%) as seen as an example in the first frame of Fig. 1. Any fluorescent cells to the right of the baseline comprised the PI stained, dead cell population. The percentage viable cells were determined by dividing the number cells in the viable fluorescent cell population as established by the control cells divided number of viable + nonviable cells and multiplying by 100. Fig. 2 showed the decrease in the percentage of viable cells as the K562 cancer cell cultures progressively die because of nutritional depletion.

Data analysis. The data collected was then graphed using PSI-Plot and whose standard procedure for graphing. The 


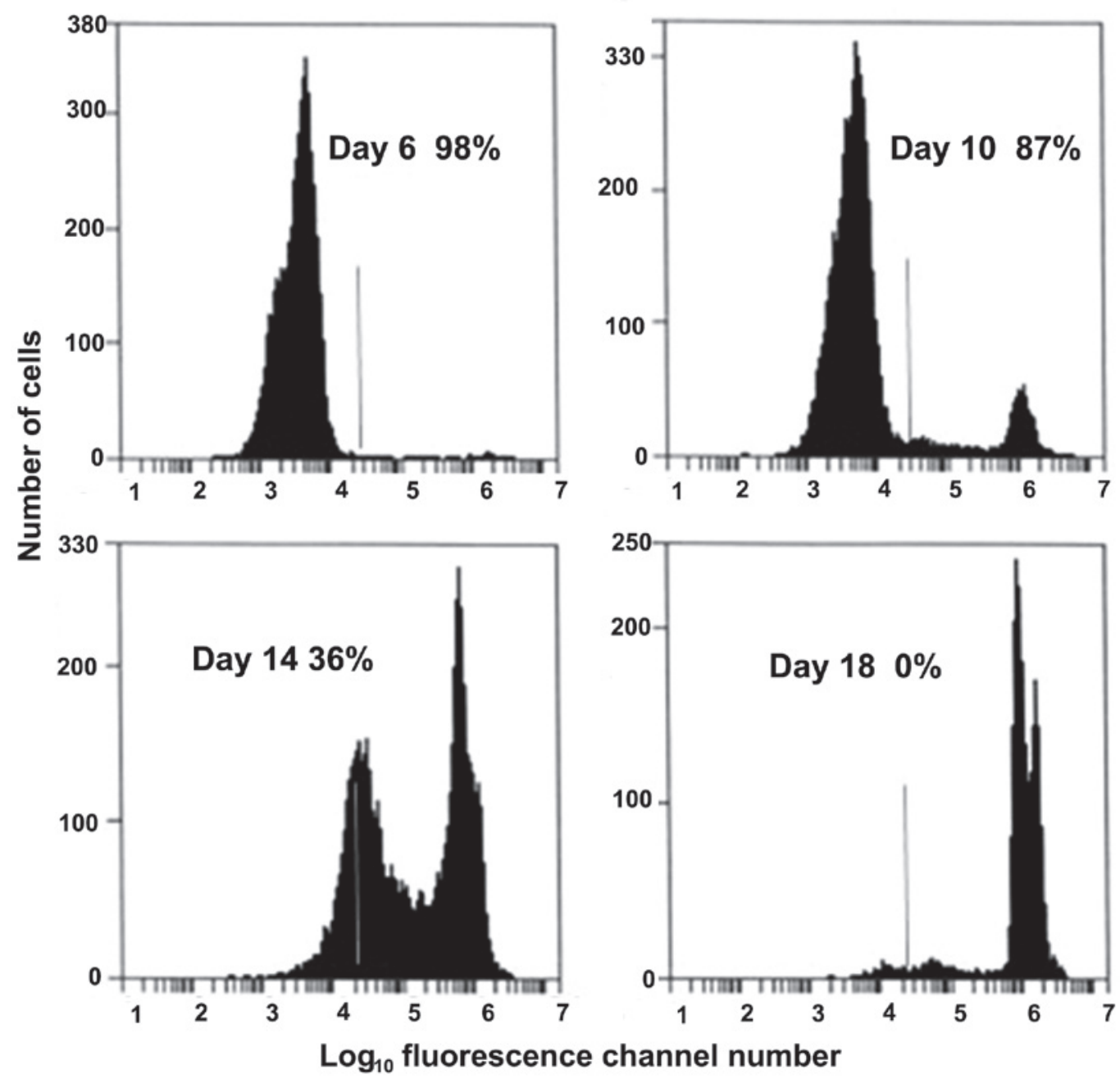

Figure 2. K562 cell viability at various days after the initial culture of $1 \times 10^{5}$ cells $/ \mathrm{ml}$. Vertical lines show the cut-off between viable and non-viable cells as measured by the uptake of the viability stain.

data was graphed in the form of percentage inhibition vs. concentration of each component. Proof of the quantitative ability of the viability stain is shown in Figs. 1 and 2. To calculate percentage inhibition, first the cell counts were multiplied by 200 to account for the 1:1 dilution of adding the PI stain, as well as the volume of the analyzed sample being $10 \mu \mathrm{l}$. Multiplication by 200 resulted in cells $/ \mathrm{ml}$. The values for the viable cells $/ \mathrm{ml}$ were incorporated into the equation, $\%$ inhibition $=(1-\mathrm{X} / \mathrm{Y}) \times 100 \%$, where $\mathrm{X}$ was equal to the cells in a particular well, and $\mathrm{Y}$ was the average number of cells in the control wells. The mean of multiple replicates (4-6) \pm the standard deviation were then determined.

The $\mathrm{LD}_{50}$ values were reported in $\mathrm{mg} / \mathrm{ml}$ per well throughout this study. All well volumes were $550 \mu \mathrm{l}$, where $500 \mu 1$ of the tumor cells had $50 \mu 1$ of the supplements at different concentrations added to their respective wells in 48-well plates (Falcon Plastics, Brookings, SD, USA). A $48 \mathrm{~h}$ incubation started with $5 \times 10^{4}$ cells and ended with about $6-7 \times 10^{4}$ cells. The initial $48 \mathrm{~h}$ incubation allowed the cells to enter exponential growth. The test supplements at various concentrations were added in $50 \mu \mathrm{l}$ to the appropriate wells. Unless noted the plates were incubated for an additional $48 \mathrm{~h}$, where the control population grew to $8-10 \times 10^{4}$ cells $/ \mathrm{ml}$.

\section{Results}

Cell viability assay. In the process of developing the viability assay used in this paper, $\mathrm{K} 562$ cells were heated at $56^{\circ} \mathrm{C}$ in $500 \mu \mathrm{l}$ aliquots at $5 \mathrm{~min}$ intervals up to $20 \mathrm{~min}$. Each sample had $500 \mu$ l of the PI-viability stain added and analyzed by flow cytometry within $30 \mathrm{~min}$ at room temperature $\left(22-24^{\circ} \mathrm{C}\right)$. In Fig. 1, gating on the K562 cancer cell forward light scatter and analyzing by red fluorescence channel $(585 \pm 20 \mathrm{~nm})$, showed the percentage of viable $\mathrm{K} 562$ cells decreased in a near linear fashion as the cells were exposed to a $56^{\circ} \mathrm{C}$ water bath for $\geq 20 \mathrm{~min}$.

Furthermore as shown in Fig. 2, the viability of expended cells in long term cultures showed two populations of dead cells: Those where the cellular membranes were compromised, and a second more PI intense population where the nuclear membranes were compromised and intercalation of the PI into double stranded DNA occurred. The percentage viability was determined from the ratio of the cells in the viable cell peak (the first one) divided by the total cells times $100 \%$. The K562 cells starting culture was $1 \times 10^{5}$ cells $/ \mathrm{ml}$. The right of the vertical line was used as the cut-off of viable (left) and non-viable (right) cells, which was established for 


\section{Size distribution by volume}

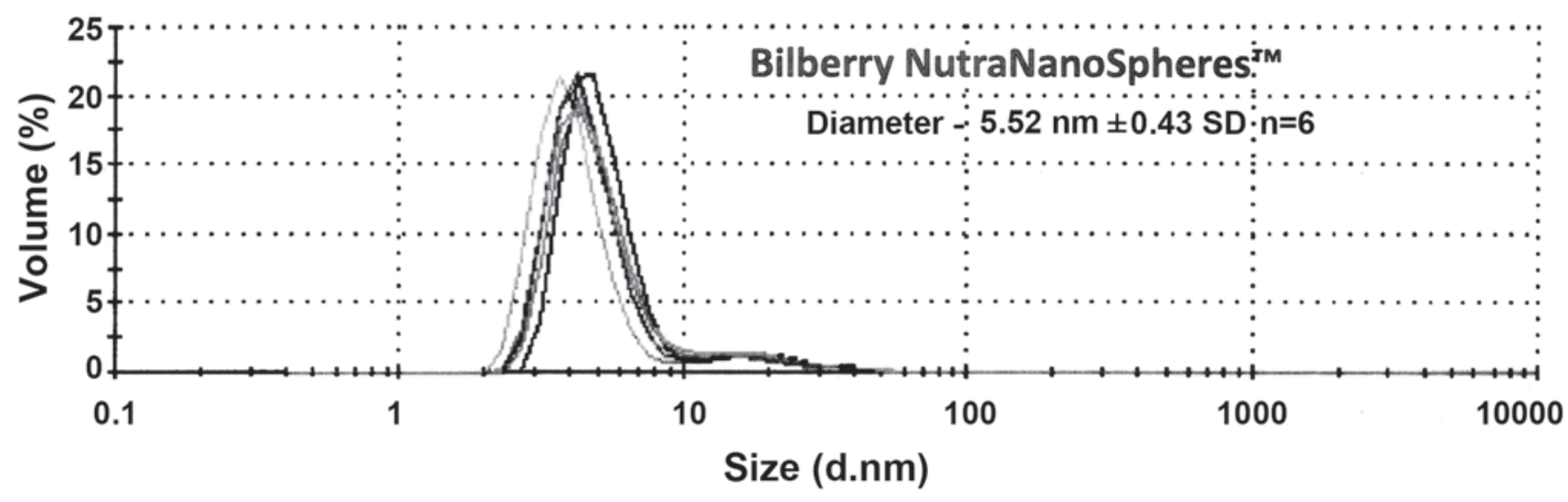

Figure 3. Size distributions by volume of the Bilberry NutraNanoSpheres ${ }^{\mathrm{TM}}$ using the Zetasizer ZSP (Malvern Instruments) to measure the sphere sizes in nm diameter. Samples were run as six replicates. Standard deviation and mean diameters are shown.

A
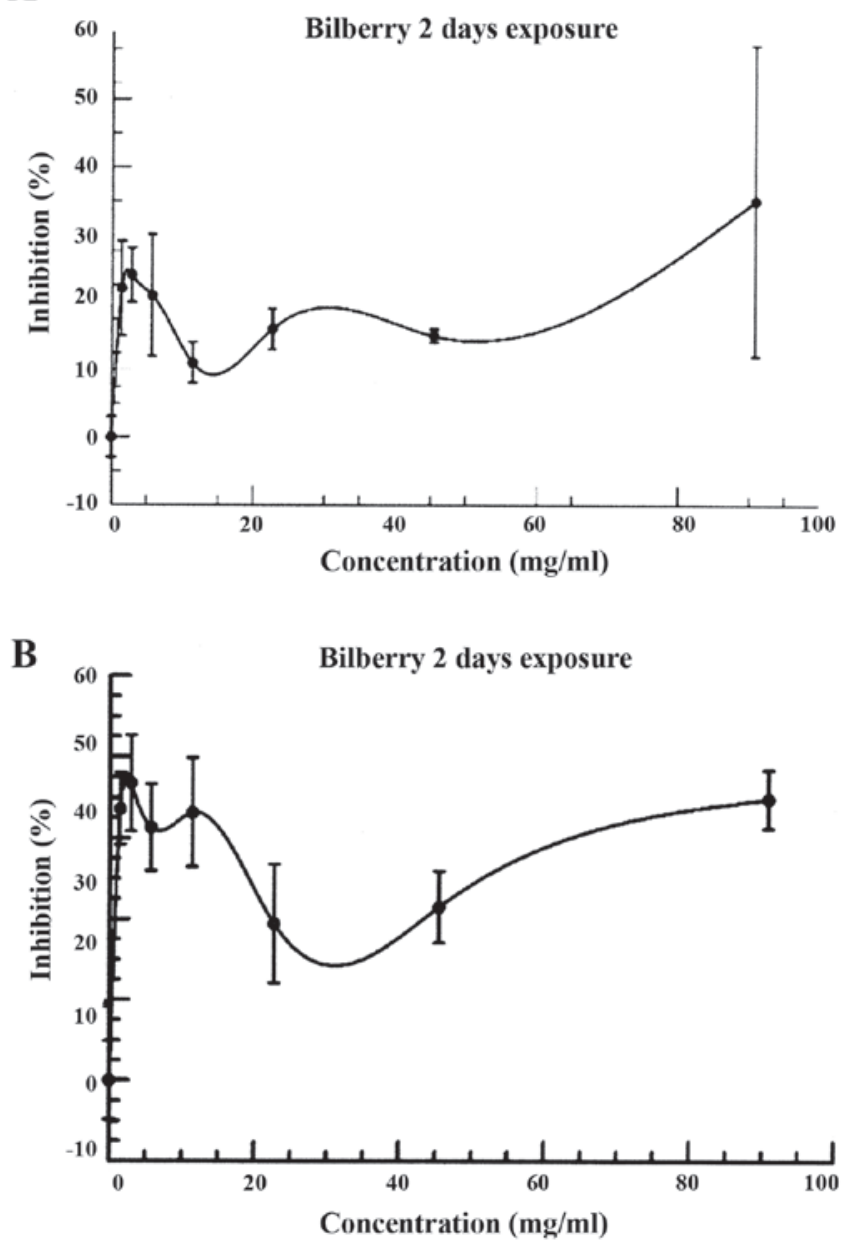

Figure 4 . The maximum percentage inhibition results occurred after an exposure for (A) 2 days ( $48 \mathrm{~h}$ ) as compared to (B) 3 days ( $72 \mathrm{~h}$ ) from $0-4.54 \mathrm{mg} / \mathrm{ml}$ of Bilberry NNS. Standard Deviation bars are shown $(n=6)$.

the control cultures (95-97\% viable). The control, viable PI population curve came to a baseline on the left of the curve, which was the beginning of the viable cell population fluorescent staining. The dead cells were to the right of the vertical line. At Day 6, the cells were 98\% viable, with up

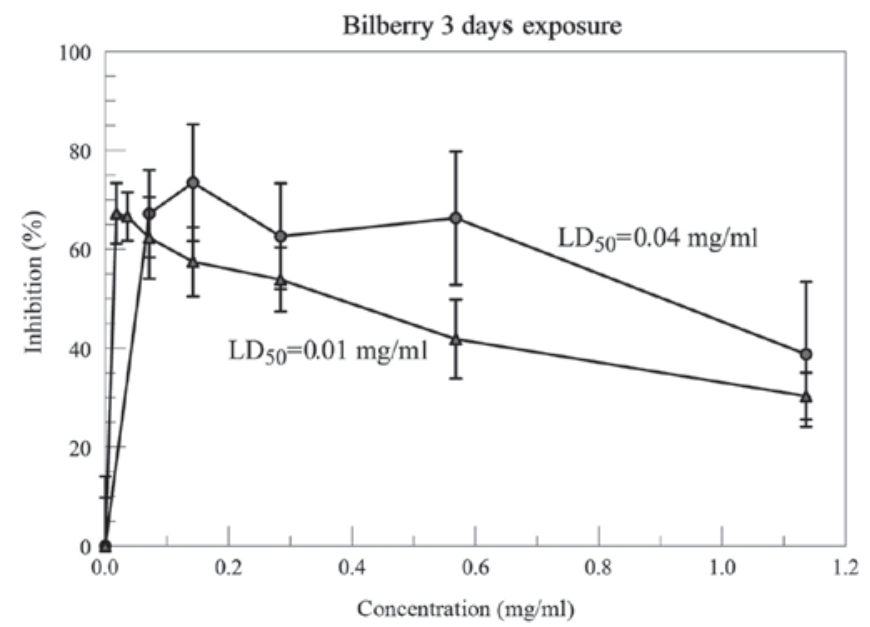

Figure 5. Detailed range from 0.01-1.14 mg/ml of Bilberry NNS. Standard deviation bars are shown $(\mathrm{n}=6)$. Two $\mathrm{LD}_{50}$ of 0.01 and 0.04 are shown.

to $1.5-2.0 \times 10^{6}$ cells $/ \mathrm{ml}$. At Day 10, dead cells were detected in the positive PI fluorescence portion of the histogram. By Days 14-18, two distinct populations of dead cells were seen, which showed the cells where the cell membrane was compromised (peak to the left of the vertical line) and cells where the nuclear membrane was compromised (peak to the right of the vertical line). This showed the PI had intercalated into the double-stranded nucleic acids, causing a very large increase in fluorescent yield. At Day 18, all of the cells were dead. There is over a 1,000-fold increase in fluorescence, which is indicative of the high fluorescence yield due to the intercalation of the Pl into the double stained nucleic acids.

The enhanced anticancer effects of encapsulating Bilberry in the NNS. The Bilberry NNS Measurements showed a greatly enhanced potent activity when these compounds were encapsulated in the liposomal structure. Fig. 3 shows the size distributions for the Bilberry NNS. The samples were diluted by volume in a ratio of 1:6 with DI Water and filtered by a $0.45 \mu \mathrm{m}$ Nylon membrane to remove any dust contaminants. These samples were run on the Malvern Zetasizer ZSP with 
a backscattering angle of 173 degrees to measure the particle size by dynamic light scattering. A non-negative least squares algorithm was used to generate the size distribution by intensity.

In Fig. 4, the maximum inhibition results occurred after an exposure for 3 days (72 h) as compared to 2 days (48 h), and a subsequent decrease by day 4 (data not shown).

By Day 3, the percentage inhibition curve between 0 and $4.54 \mathrm{mg} / \mathrm{ml}$ showed two, possibly three regions of inhibition about $.25, .75$, and $4.54 \mathrm{mg} / \mathrm{ml}$. A dramatic increase in the inhibition of the cancer cells was seen between Day 2 and 3 . In Fig. 5, the $0.25 \mathrm{mg} / \mathrm{ml}$ inhibition region was expanded from $0.01-1.14 \mathrm{mg} / \mathrm{ml}$ for the Bilberry NNS. The $\mathrm{LD}_{50}$ in two experiments were 0.01 and $0.04 \mathrm{mg} / \mathrm{ml}$. The published data shows the $\mathrm{LD}_{50}$ is $\sim 0.3-0.4 \mathrm{mg} / \mathrm{ml}$ at Bilberry concentrations of $50 \mathrm{mg} / \mathrm{ml}$ for the stock solution (5). This shows an increase in the cytotoxicity of the Bilberry NNS of 8-40 times the published free bilberry.

\section{Discussion}

The most promising anticarcinogenic agents in plants are phenolic compounds, which are abundantly present in Bilberries (Vaccinium myrtillus), and a variety of others including lingonberry (Vacciniumvitis-idaea), and cloudberry (Rubus chamaemorus) (3,6-8). Anthocyanins are hydrophilic compounds, predictably unable to cross the cell plasma membrane by passive diffusion (9). Therefore, without a hydrophilic carrier, such as the NNS, which also have a hydrophobic, fatty acid component that 'melts' into cell membranes to deposit the Bilberry into the cancer cells, one could understand the poor bioavailability of the anthocyanins $(10,11)$. The results obtained show that the bilberry extract does have an increased anti-cancer effect when it is encapsulated compared to the free compound. Experiments were performed to determine if there was an effect, first of all, and then when that effect was strongest. As shown in Fig. 4, the inhibition at $72 \mathrm{~h}$ was much more pronounced than $48 \mathrm{~h}$. However, at $96 \mathrm{~h}$, the results were similar to the $24 \mathrm{~h}$ percentage inhibition curve due to, in part, the metabolic destruction of the anthocyanins and cell culture nutritional depletion.

Besides its role in fighting cancer, Bilberry is an effective support against type 2 Diabetes (12-15), vision improvement (16-18), obesity (19-21), cancer prevention (22-24), ulcerative colitis (25), anti-inflammatory $(26,27)$, antioxidant $(28,29)$, and gingival inflammation (30).

In conclusion, the direct cytotoxic effects of the NNS Bilberry showed $\mathrm{LD}_{50}$ levels 8-40 times lower than what is required for the Bilberry that is not encapsulated. The increase in bioavailability with the Bilberry NNS and its water solubility show the feasibility of using Bilberry NNS in cancer patient clinical trials. Furthermore, the NNS Bilberry can be used as a preventive supplement that is freely water soluble, consisting of a micelle formulation that is $5.5 \mathrm{~nm}$ in diameter with a well-defined dosage per NNS. The stability of this NNS preparation enables its combination with other NNS supplements by simply adding drops together in a beverage. Some of the NNS preparations that have been successfully micellized using the NNS methodology include Vitamins $\left(C, B 12, D_{3}, E\right)$, $\mathrm{CQ}_{10}$, Curcumin, Artemisinin, Frankincense, Riboside
Nucleotide, Acemanan, among others. Finally, all of our NNS preparations survive the stomach and intestines and fuse with the intestinal cell walls and deposited into the bloodstream with a bioavailability exceeding $90 \%$.

\section{Acknowledgements}

The present study was conducted at the Cancer Research Institute of West Tennessee, under the direction of Dr Jerry Thornthwaite, who provided all of the materials and equipment used. This research was supported in part by generous donations from Mr. Henry Respess, The Shumard Foundation and the Carter Family Trust. We thank Dr Carrie Schindler for the Malvern Zetasizer Nano System analyses of the sizing of the NutraNanoSpheres. We thank Dr Tony Kirk, and Bonita Thornthwaite for reviewing this manuscript. Special thanks goes to Dr Lothar Haegele of X-Labs (Singapore) for supplying the curcumin and vitamin C NutraNanoSpheres ${ }^{\mathrm{TM}}$ preparations for this study.

\section{References}

1. Thomasset S, Berry DP, Cai H, West K, Marczylo TH, Marsden D, Brown K, Dennison A, Garcea G, Miller A, et al: Pilot study of oral anthocyanins for colorectal cancer chemoprevention. Cancer Prev Res (Phila) 2: 625-633, 2009.

2. Sehitoglu MH, Farooqi AA, Qureshi MZ, Butt G and Aras A: Anthocyanins: Targeting of signaling networks in cancer cells. Asian Pac J Cancer Prev 15: 2379-2381, 2014.

3. Alhosin M, León-González AJ, Dandache I, Lelay A, Rashid SK, Kevers C, Pincemail J, Fornecker LM, Mauvieux L, Herbrecht R and Schini-Kerth VB: Bilberry extract (Antho 50) selectively induces redox-sensitive caspase 3-related apoptosis in chronic lymphocytic leukemia cells by targeting the Bcl-2/Bad pathway. Sci Rep 5: 8996, 2015.

4. Kausar H, Jeyabalan J, Aqil F, Chabba D, Sidana J, Singh IP and Gupta RC: Berry anthocyanidins synergistically suppress growth and invasive potential of human non-small-cell lung cancer cells. Cancer Lett 325: 54-62, 2012.

5. Nguyen V, Tang J, Oroudjev E, Lee CJ, Marasigan C, Wilson L and Ayoub G: Cytotoxic effects of bilberry extract on MCF7-GFP-tubulin breast cancer cells. J Med Food. 13: 278-285, 2010.

6. Misikangas M,Pajari AM,PäivärintaE,Oikarinen SI,Rajakangas J, Marttinen M, Tanayama H, Törrönen R and Mutanen M: Three nordic berries inhibit intestinal tumorigenesis in Min/+ mice by modulating beta-catenin signaling in the tumorand transcription in the mucosa1. J Nutr 137: 2285-2290, 2007.

7. Mutanen M, Pajari AM, Paivarinta E, Misikangas M, Rajakangas J, Marttinen M and Oikarinen S: Berries as chemopreventive dietary constituents-a mechanistic approach with the ApcMin/+ mouse. Asia Pac J Clin Nutr 17 (Suppl): S123-S125, 2008.

8. Wang Y, Zhao L, Lu F, Yang X, Deng Q, Ji B and Huang F: Retinoprotective effects of bilberry anthocyanins via antioxidant, anti-inflammatory and anti-apoptotic mechanisms in a visible light-induced retinal degeneration model in pigmented rabbits. Molecules 20: 22395-22410, 2015.

9. Walton MC, McGhie TK, Reynolds GW and Hendriks WH: The flavonol quercetin-3-glucoside inhibits cyanidin-3-glucoside absorption in vitro. J Agric Food Chem 54: 4913-4920, 2006.

10. Sakakibara H, Ichikawa Y, Tajima S, Makino Y, Wakasugi Y, Shimoi K, Kobayashi S, Kumazawa S and Goda T: Practical application of flavonoid-poor menu meals to the study of the bioavailability of bilberry anthocyanins in human subjects. Biosci Biotechnol Biochem 78: 1748-1752, 2014.

11. Walle T: Methylation of dietary flavones increases their metabolic stability and chemopreventive effects. Int J Mol Sci 10: 5002-5019, 2009.

12. Kim J, Kim CS, Lee YM, Sohn E, Jo K and Kim JS: Vaccinium myrtillus extract prevents or delays the onset of diabetes-induced blood-retinal barrier breakdown. Int J Food Sci Nutr 66: 236-42, 2015. 
13. Singh S, Netticadan T and Ramdath DD: Expression of cardiac insulin signaling genes and proteins in rats fed a high-sucrose diet: Effect of bilberry anthocyanin extract. Genes Nutr 11: 8, 2016.

14. Moshetova LK, Vorob'eva IV, Alekseev IB and Mikhaleva LG: (Results of the use of antioxidant and angioprotective agents in type 2 diabetes patients with diabetic retinopathy and age-related macular degeneration). Vestn Oftalmol 131: 34-44, 2015 (In Russian).

15. Asgary S, RafieianKopaei M, Sahebkar A, Shamsi F and Goli-malekabadi N: Anti-hyperglycemic and anti-hyperlipidemic effects of Vaccinium myrtillus fruit in experimentally induced diabetes (antidiabetic effect of Vaccinium myrtillus fruit). J Sci Food Agric 96: 764-768, 2016.

16. Cheng YP, Ke CY, Kuo CC and Lee YJ: Effect of a complex lutein formula in an animal model for light-induced retinal degeneration. Chin J Physiol 59: 202-209, 2016.

17. Vorob'eva IV and Vorob'eva IV: Current data on the role of anthocyanosides and flavonoids in the treatment of eye diseases. Vestn Oftalmol 131: 104-110, 2015.

18. Ozawa Y, Kawashima M, Inoue S, Inagaki E, Suzuki A, Ooe E, Kobayashi S and Tsubota K: Bilberry extract supplementation for preventing eye fatigue in video display terminal workers. J Nutr Health Aging 19: 548-554, 2015.

19. Van der Heijden RA, Morrison MC, Sheedfar F, Mulder P, Schreurs M, Hommelberg PP, Hofker MH, Schalkwijk C, Kleemann R, Tietge UJ, et al: Effects of anthocyanin and flavanol compounds on lipid metabolism and adipose tissue associated systemic inflammation in diet-induced obesity. Mediators Inflamm 2016: 2042107, 2016.

20. Takahashi A, Shimizu H, Okazaki Y, Sakaguchi H, Taira T, Suzuki T and Chiji H: Anthocyanin-rich phytochemicals from aronia fruits inhibit visceral fat accumulation and hyperglycemia in high-fat diet-induced dietary obese rats. J Oleo Sci 64: 1243-1250, 2015

21. Taira T, Yamaguchi S, Takahashi A, Okazaki Y, Yamaguchi A Sakaguchi H and Chiji H: Dietary polyphenols increase fecal mucin and immunoglobulin A and ameliorate the disturbance in gut microbiota caused by a high fat diet. J Clin Biochem Nutr 57: 212-216, 2015

22. Hou DX: Potential mechanisms of cancer chemoprevention by anthocyanins. Curr Mol Med 3: 149-159, 2003.
23. Popović D, Đukić D, Katić V, Jović Z, Jović M, Lalić J, Golubović I, Stojanović S, Ulrih NP, Stanković M and Sokolović D: Antioxidant and proapoptotic effects of anthocyanins from bilberry extract in rats exposed to hepatotoxic effects of carbon tetrachloride. Life Sci 157: 168-177, 2016.

24. Aqil F, Jeyabalan J, Munagala R, Singh IP and Gupta RC: Prevention of hormonal breast cancer by dietary jamun. Mol Nutr Food Res 60: 1470-1481, 2016

25. Roth S, Spalinger MR, Gottier C, Biedermann L, Zeitz J, Lang S, Weber A, Rogler G and Scharl M: Bilberry-derived anthocyanins modulate cytokine expression inthe intestine of patients with ulcerative colitis. PLoS One 11: e0154817, 2016.

26. Nardi GM, Farias Januario AG, Freire CG, Megiolaro F, Schneider K, Perazzoli MR, Do Nascimento SR, Gon AC, Mariano LN, Wagner G, et al: Anti-inflammatory activity of berry fruits in mice model of inflammation is basedon oxidative stress modulation. Pharmacognosy Res 8 (Suppl 1): S42-S49, 2016.

27. Colak N, Torun H, Gruz J, Strnad M, Hermosín-Gutiérrez I, Hayirlioglu-Ayaz S and Ayaz FA: Bog bilberry phenolics, antioxidant capacity and nutrient profile. Food Chem 201: 339-349, 2016.

28. Jakesevic M, Aaby K, Borge GI, Jeppsson B, Ahrné S and Molin G: Antioxidative protection of dietary bilberry, chokeberry and Lactobacillus plantarum HEAL19 in mice subjected to intestinal oxidative stress by ischemia-reperfusion. BMC Complement Altern Med 11: 8, 2011.

29. Bornsek SM, Ziberna L, Polak T, Vanzo A, Ulrih NP, Abram V, Tramer F and Passamonti S: Bilberry and blueberry anthocyanins act as powerful intracellular antioxidants in mammalian cells. Food Chem 134: 1878-1884, 2012.

30. Widén C, Coleman M, Critén S, Karlgren-Andersson P, Renvert S and Persson GR: Consumption of bilberries controls gingival inflammation. Int J Mol Sci 16: 10665-10673, 2015. 